
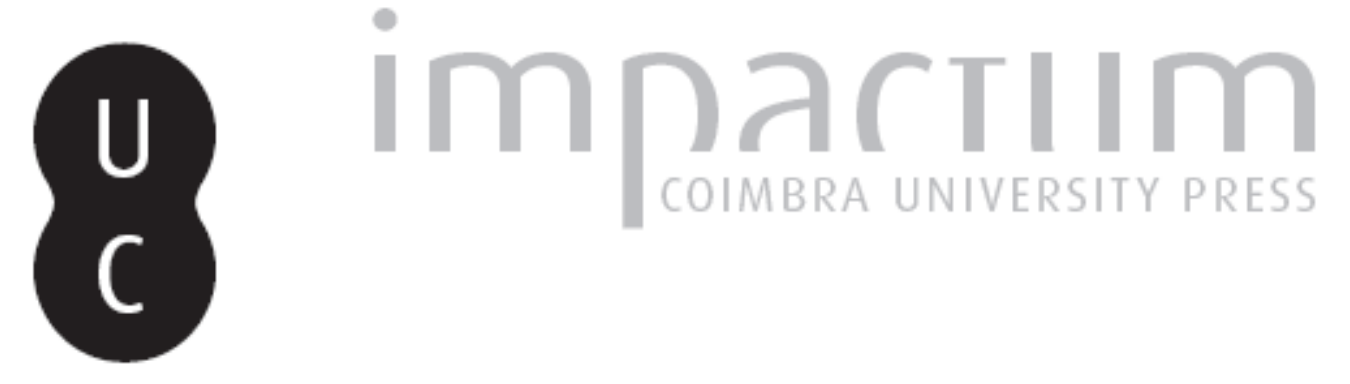

\title{
The last lusitanian senator
}

\section{Autor(es): $\quad$ Curchin, Leonard A.}

Publicado por: Faculdade de Letras da Universidade de Coimbra

URL persistente:

URI:http://hdl.handle.net/10316.2/37861

DOI:

DOI:http://dx.doi.org/10.14195/1647-8657_49_5

Accessed : $\quad$ 26-Apr-2023 13:14:47

A navegação consulta e descarregamento dos títulos inseridos nas Bibliotecas Digitais UC Digitalis, UC Pombalina e UC Impactum, pressupõem a aceitação plena e sem reservas dos Termos e Condições de Uso destas Bibliotecas Digitais, disponíveis em https://digitalis.uc.pt/pt-pt/termos.

Conforme exposto nos referidos Termos e Condições de Uso, o descarregamento de títulos de acesso restrito requer uma licença válida de autorização devendo o utilizador aceder ao(s) documento(s) a partir de um endereço de IP da instituição detentora da supramencionada licença.

Ao utilizador é apenas permitido o descarregamento para uso pessoal, pelo que o emprego do(s) título(s) descarregado(s) para outro fim, designadamente comercial, carece de autorização do respetivo autor ou editor da obra.

Na medida em que todas as obras da UC Digitalis se encontram protegidas pelo Código do Direito de Autor e Direitos Conexos e demais legislação aplicável, toda a cópia, parcial ou total, deste documento, nos casos em que é legalmente admitida, deverá conter ou fazer-se acompanhar por este aviso.

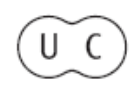


CONIMBRIGA

C)

CN N N

INSTITUTO DE ARQUEOLOGIA

VOLUME XLIX • 2010

FACULDADE DE LETRAS 
LEONARD A. CURCHIN

Classical Studies. University of Waterloo (Canada)

lcurchin@uwaterloo.ca

\section{THE LAST LUSITANIAN SENATOR}

"Conimbriga" XLIX (2010) p. 87-96

SUMMARY: The last known senator from Lusitania is Valerius Fortunatus, known to us from Oration VIII by Symmachus. The author presents an annotated translation of this speech, together with a discussion of this senator's family and career.

RÉSUMÉ: Valerius Fortunatus est le dernier sénateur lusitanien de notre connaissance, grâce au témoinage de Symmaque dans son Oration VIII. On présente ici une traduction commentée de ce discours. En plus, on discute la famille et la carrière de ce sénateur.

SUMARIO: El último senador lusitano que conocemos es Valerius Fortunatus, mencionado en la Oración VIII de Symmaco. Se presenta aquí una traducción anotada de la misma, con una discusión de la familia y la carrera de este senador. 
(Página deixada propositadamente em branco) 


\section{THE LAST LUSITANIAN SENATOR}

Professor Étienne was keenly interested in Roman senators of Hispanic origin, particularly those from Lusitania (ÉTIENNE 1965; ÉTIENNE 1982). One senator absent from his catalogue of Lusitanian senators is Valerius Fortunatus of Emerita, in the late fourth century A.D. (Jones - MARTINDALE - MoRris 1971: 370-371). This senator is known to us only from Oration VIII by Symmachus. While the Latin text of this speech, preserved in Codex Vaticanus Latinus 5750, has been known since 1815 (SEECK 1883: 338-339) ${ }^{1}$ and has been translated into French by ChastaGnol (1970: 210-11) and into German by PABST (1989: 121-123), there exists no translation into English. I shall first remedy this omission, noting minor defects in the two previous translations, then discuss Valerius Fortunatus and his ill-starred family and career.

\section{Annotated Translation:}

“ (1) [... she had heard that the beaver, when it is beset by danger,] bargains ${ }^{2}$ for its life by biting off the part of its own body that is desirable ${ }^{3}$. The mother of the family turned this principle to the advantage of her children, but with greater loss, as she managed their scarce funds too timidly; yet she complained quite correctly that she had rescued less than she sacrificed.

1 See PABST 1989: 359 for a list of earlier editions.

2 pacisci means "to contract, bargain". Chastagnol and Pabst less accurately translate as "save" ("il sauve la vie"; "sein Leben rettet").

3 The testicles of the beaver were prized for the medicinal qualities of their oil. It was believed that beavers would castrate themselves to avoid being killed by hunters (Plin. NH 8, 47, 109; Isid. Etym. 12, 2, 21).

Conimbriga, 49 (2010) 87-96 
(2) Picture to yourselves ${ }^{4}$, conscript fathers, a matron kneeling and laying her son's insignia before the feet of the emperors. She suffers, poor woman, both for what she laments and for what she requests 5 . For certainly she could have sought a quaestorship consistent with her finances, as we do now; but being conscious of her poverty, she feared that even this, which is barely more than nothing, would be very heavy. It was at your discretion, conscript fathers, to censure Fortunatus' deception ${ }^{6}$, because despite having subsequently experienced no increase in his family finances, he aspired to pay an amount, albeit a very small one, beyond what his mother declared ${ }^{7}$.

(3) But, to resume the course of my story, for a long time parsimony $(?)^{8}$ was a comfort for this unfortunate man. After he reached adulthood, he was moved - perhaps by the impulse of noble blood, which always recognizes itself - to a desire of recovering what he had obtained by birth; for, as far as I know, his confidence had not been bolstered by any influx of new assets. He petitioned, against the entreaties of his mother - why do I say his mother? He petitioned against himself, before

4 Literally, "place an image under your eyes"

5 An intrusive gloss, rightly bracketed by Seeck, adds, "that is, lack of money and the humiliation of the request".

6 The meaning is clearly that the Senate could have chastized Fortunatus for deceiving them with his earlier plea (through his mother) that he lacked the wealth to be a senator, when he was later able to offer to pay more money for admission to the Senate than she had claimed he owned. I do not understand why Chastagnol translates Fortunati ostentationem notare as "de fixer le montant des frais imposés à Fortunatus": the meaning of ostentatio as "deception", and of notare as "to stigmatize", is amply attested.

What is this "very small" amount of money that Fortunatus was able to pay to become a senator? It cannot be the cost of quaestorial games, which was neither small nor within his means. Symmachus is presumably referring to the gleba, "which was a graded surtax but of negligible weight" (JONES 1973: 465).

8 Seeck restores $t$ [enuit]as, which means "thinness, poverty". To the best of my knowledge, it does not mean "tenderness of age". Lexically, therefore, Chastagnol's "sa pauvreté" is a better translation than Pabst's "seine Jugend". However, it is unclear how poverty could be a relief (remedio fuit) to anyone, unless Symmachus is being sarcastic. Instead I propose $t$ [enacit] as "parsimony, miserliness". By tightly controlling his spending, Fortunatus was able to preserve his inheritance and eventually make a bid for the Senate.

Conimbriga, 49 (2010) 87-96 
the Senate ${ }^{9}$. And by chance, at that time ${ }^{10}$ the city council of Emerita arraigned him for so great a lack of dignity ${ }^{11}$, thinking that Fortunatus' resources at least met their own modest standard. The lawsuit proceeded to court: many things were said about his lineage and restoring the glory of his family, which might have been sufficiently strong to win his case; but what helped even more was that he did not seem suitable even to the plaintiffs ${ }^{12}$. They therefore gave up this unprofitable struggle, and thus our candidate for the quaestorship succeeded, not so much in becoming a senator as in avoiding impoverishment ${ }^{13}$.

(4) Now try to pick the time at which he, if he should ever have been obliged at all, could have been called upon to undertake the cost of such games. In the first years of his life he had given up being a senator; in the following years he struggled not to be incorporated into a lesser kind of senate. Could you have appointed a man who was either an outsider through the mercy of the first petition, or of uncertain status under threat of the trial that followed?

(5) I realize that your Amplitude ${ }^{14}$ did not know these things for a long time, and therefore had no reason to think, because of ignorance

9 pro senatu means "in front of the Senate" (thus Chastagnol, "devant le Sénat"). Although pro sometimes means "for" in the sense "on behalf of" or "in return for", the phrase cannot mean "for (a seat in) the Senate" ("um seinen Sitz im Senat": Pabst). The nature of Fortunatus' petition is in any case made clear later in the paragraph: he had applied, successfully, for admission to the Senate (senator obtinuit).

10 Despite Symmachus' eloquent reference to Fortunatus being moved by his noble blood, it is obvious that his real reason for seeking Senate membership was to avoid municipal obligations. Therefore the filing of the lawsuit by the councillors of Emerita must have preceded his petition to be restored to the Senate. Symmachus deliberately presents events in the reverse order, to give the impression that Fortunatus was already seeking a Senate seat prior to his contest with the local council, and then pretends that they were contemporaneous (eo tempore).

11 I.e., he now lacked the senatorial status that would have exempted him from curial duties.

12 I take illis "those (men)" as referring to the Emeritenses (so Pabst: "jenen Leuten"), who are also the understood subject of rennuerunt in the next sentence. However, illis idoneus could also mean "suitable for those (duties)" (so Chastagnol: "apte à remplir ces charges").

13 I.e., he avoided expensive liturgies at Emerita.

14 An allusion to the ordo amplissimus, on which see CHASTAGnol 1986: 75. Constantine had increased the size of the Roman Senate from 600 to about 2000

Conimbriga, 49 (2010) 87-96 
of those [circumstances, that Fortunatus should be relieved of such expenses $(?)^{15} \ldots . . "$

\section{Discussion}

The date of this speech can only be stated approximately. STROHEKER (1963: 120) dates it "vor 377", PABST (1989: 20) "nach 376". How can it be after 376 but before 377? Stroheker relies on Seeck, who believes that all eight speeches of Symmachus either should or at least could have been composed before $377^{16}$. However, assuming the speeches were arranged in roughly chronological order, as the first six suggest (I and III 369; II 370; IV-V 376; VI between 376 and 378), it is likely that VII and VIII postdate 376 . All we can conclude is that Oration VIII probably dates to about 377 .

It is apparent that Valerius Fortunatus was the scion of a senatorial family of Emerita. His father, undoubtedly also a Valerius, should be added to the list of known Lusitanian senators. Unfortunately, because Valerius is one of the commonest Latin nomina in the Iberian Peninsula, it is not possible to connect the family of Valerius Fortunatus with the numerous Valerii attested at Emerita, such as the flaminica perpetua Valeria Viniciana (CIL II, 494) ${ }^{17}$. The cognomen Fortunatus is also well attested in Lusitania, including several examples at Emerita (GRUPO MÉRIDA 2003: 178, bizarrely omitting Valerius Fortunatus).

The troubled history of Valerius Fortunatus may be reconstructed as follows. As the son of a Roman senator, he should have expected to be admitted to the Senate when he came of age ${ }^{18}$. In order to become a senator, a young man of noble birth (clarissimus puer) was required by tradition to hold a quaestorship (quaestura), though this was no

members, though many of them resided in the provinces. Attendance at Senate meetings was sufficiently poor that by the mid-fourth century it became necessary to require a quorum of 50 members (Cod. Theod. 6, 4, 9).

15 My restoration.

16 "Omnes eiusmodi sunt, ut ante a. 377 compositae esse aut debeant aut certe possint": SEECK 1883: p. X.

17 Saquete Chamizo 1997: 76 counts 49 Valerii at Emerita.

18 A boy was normally considered to become an adult at the age of sixteen, although magistrates in the Late Empire could be as young as thirteen (MARCONE 1998: 355). Symmachus himself held three magistracies before the age of twenty.

Conimbriga, 49 (2010) 87-96 
longer an important magistracy but a ceremonial office whose principal responsibility was paying for public spectacles. Quaestors had been obliged to provide games (quaestoria munera) since the reign of Domitian (Suet. Dom. 4). In the fourth century, clarissimi were obliged to come to Rome in person to present and pay for these displays (Cod. Theod. 6, 4, $4 ; 6,4,7)$. Normally the cost of quaestorial games would be borne by the young man's father, who controlled the family finances (MATTHEWS 1975: 13). In Fortunatus' case, however, his father was dead and his family impecunious. To avoid the expense of the quaestorship, his mother did not request a financial subsidy (which is what Symmachus seeks in this speech) but rather that her son be exempt from becoming a senator at all ${ }^{19}$. She achieved this by petitioning the emperors, which must mean Valentinian (western emperor 364-375) and his son Gratian, who had become Augustus in 367. Since these emperors spent most of their time at Trier, her petition would presumably have been sent to them there.

But the success of his mother's request moves Fortunatus out of the frying pan and into the fire. Senatorial status exempted one from serving as a member of the local curia. Having forfeited this exemption, Fortunatus was liable for munera at Emerita, whose curia seized upon his lack of senatorial status (vacuum dignitatis: VIII, 3) and pursued him aggressively. Had they succeeded, he could have been obliged to sponsor ludi in the circus, the theatre or the amphitheatre. Members of the local curia might also be financially liable for maintenance of the baths and collection of taxes (SAQUeTe Chamizo 1997: 91). The case came to trial, but it was precisely Fortunatus' inability to meet the financial obligations even of a local curial that finally persuaded the Emeritenses to abandon the lawsuit as a lost cause.

Meanwhile, Fortunatus had applied for reinstatement to senatorial status (restitutio in integrum). In view of his noble blood, Fortunatus apparently had no difficulty gaining senatorial admission; but this of course rendered him liable for quaestoria munera, which he could not afford ${ }^{20}$. Why Fortunatus did not foresee this obvious hurdle is unclear.

19 Because of the hereditary nature of status in the late empire, clarissimi pueri were obliged to become senators unless excused by the emperor (JONES 1973: 530, cf. $523)$.

20 We know neither the cost of quaestoria munera, nor the amount of wealth required to meet the senatorial census in this period (CHASTAGNOL 1986: 80). For the praetorian games at least, Olympiodorus (frag. 44) records expenditures from

Conimbriga, 49 (2010) 87-96 
Perhaps he was so desperate to avoid the immediate threat of local munera that he decided to make a bid for the Senate first, and worry about paying for it later; or perhaps he thought he could become a clarissimus (member of the senatorial order) without holding a quaestorship ${ }^{21}$. In the event, Fortunatus has Symmachus plead for what his mother failed to request, a quaestorship fitted to his means (VIII, 2: convenientem censibus suis...quaesturam). Symmachus here is distinguishing between two types of quaestors: quaestores candidati, who paid for munera and were subsequently eligible to stand for the praetorship and then a provincial command; and quaestores arcarii, poorer senators who received a financial subsidy from government coffers (arca fisci) to organize less lavish entertainments, and for whom the quaestorship was a terminal office ${ }^{22}$. In granting Fortunatus' earlier request for admission, the Senate had made him a candidatus (VIII, 3: noster hic quaestorius candidatus); now Symmachus requests that his condition be changed to that of an arcarius. The fact that Symmachus published this speech suggests that his appeal was successful. Thus we may postulate that Fortunatus managed to retain the status of vir clarissimus while evading the financial burdens associated with the quaestorship.

The story of Fortunatus as recounted by Symmachus throws an interesting light on the Roman Senate in the late fourth century. It appears from his mother's petition that senatorial membership in this period was both hereditary and compulsory ${ }^{23}$. Fortunatus would have automatically become a senator like his father, with the attendant financial obligations, unless granted an exemption (excusatio) by the emperors. It also appears, as JONES $(1973: 530,1223)$ points out, that admission to the Senate was

12 centenaria (1200 pounds of gold) to 40 centenaria ( 4000 pounds), but these are mentioned as unusually high amounts.

21 All senators were clarissimi, but not all clarissimi were senators: CHASTAGNOL 1986: 74

22 Quaestores candidatos ex sua pecunia iussit munera populo dare, sed ita ut post quaesturam praeturas acciperent et deinde provincias regerent; arcarios vero instituit, qui de arca fisci ederunt munera eademque parciora: Hist. Aug. Alex. Sev. 43, 3-4. As Chastagnol (1970: 193) points out, this distinction, though anachronistically assigned by the Historia Augusta to Alexander Severus, is really applicable only to the fourth century.

23 Cod. Theod. 6, 2, 13 refers to men becoming senators "by the luck of their birth" (generis felicitate).

Conimbriga, 49 (2010) 87-96 
dependent on the quaestorship ${ }^{24}$. The mother of Fortunatus surrendered his senatorial rank to avoid the expenses of the quaestorship, and when he regained it, he was promptly made a quaestor candidatus.

Thus, the case of Valerius Fortunatus illuminates our knowledge not only of late Roman elite families in the city of Emerita, but also of the ways in which Roman senators in this period could begin their entry into the cursus honorum.

\section{BIBLIOGRAPHY}

ARNHeIM, M.T.W. (1972) - The senatorial aristocracy in the later Roman empire, Oxford 1972.

Chastagnol, André (1970) - "Les modes de recrutement du Sénat au IV siècle après J.-C.", Recherches sur les structures sociales dans l'Antiquité classique, Caen, 25-26 avril 1969, Paris 1970 187-211.

Chastagnol, André (1986) - "Le Sénat dans l'oeuvre de Symmaque", Colloque genevois sur Symmaque, ed. F. Paschoud, Paris 1986 73-96.

ÉTIENNE, Robert (1965) - "Les sénateurs espagnols sous Trajan et Hadrien", Les empereurs romains d'Espagne, Paris 1965 55-85.

ÉtIENNE, Robert (1982) - "Sénateurs originaires de la province de Lusitanie", Tituli $51982521-529$.

GRUPO MÉRIDA (2003) - Atlas antropon 'mico de la Lusitania romana, Mérida - Burdeos 2003.

JoNES, A.H.M. (1973) - The later Roman empire, Oxford 1973.

Jones, A.H.M. - MARTINDALE, J.R. - MorRIs, J. (1971) - The prosopography of the later Roman empire, vol. I, Cambridge 1971.

MARCONE, Arnaldo (1998) - "Late Roman social relations", Cambridge Ancient History vol. XIII, ed. Averil Cameron and Peter Garnsey, Cambridge 1998 338-370.

MAtTHEWs, John (1975) - Western aristocracies and imperial court AD 364-425, Oxford 1975.

24 Although Chastagnol (1970: 191) contends that "c'était la préture qui donnait accès au Sénat, et non plus la questure", the law he cites (Cod. Theod. 6, 4, 7) does not support this view; it does not even mention the praetorship. Hypothetically, Symmachus' reference to Fortunatus as a senator (VIII, 3) could mean that he was a member of the senatorial order (i.e. a clarissimus) but not actually of the Senate (Chastagnol's "l'Assemblée sénatoriale"). However, this possibility is rejected by Chastagnol himself: noting that Symmachus in Relatio XLVIII uses the word senatores in the wider sense of clarissimi, he observes, "Dans les autres occurrences, senator se réfère bien à un membre de l'Assemblée" - and he cites our passage Orat. VIII, 3 (Chastagnol 1986: 74). It is true, however, that some non-nobles entered the Senate as praetors rather than quaestors: ARNHEIM 1972: 14-15.

Conimbriga, 49 (2010) 87-96 
PABSt, Angela (1989) - Quintus Aurelius Symmachus: Reden, Darmstadt 1989.

Saquete Chamizo, J.C. (1997) - Las elites sociales de Augusta Emerita, Mérida 1997.

SEECK, Otto (1883) - Q. Aurelii Symmachi quae supersunt = Monumenta Germaniae Historica, Auctores Antiquissimi, vol. VI.1, Berlin 1883.

STroheKer, K.F. (1963) - "Spanische Senatoren der spätrömischen und westgotischen Zeit”, Madrider Mitteilungen 41963 107-132.

Conimbriga, 49 (2010) 87-96 